OPEN ACCESS

Edited by:

Nicola Mucci,

University of Florence, Italy

Reviewed by:

Alberto Ferraris,

University of Turin, Italy

Abel Lucena,

University of the Balearic

Islands, Spain

*Correspondence:

Xinhua Bi

bixh@jlu.edu.cn

Specialty section

This article was submitted to Organizational Psychology,

a section of the journal

Frontiers in Psychology

Received: 28 September 2020 Accepted: 18 March 2021 Published: 27 April 2021

Citation:

Zhao A, Bi X and Han L (2021) Re-examining the New Product Paradox: How Innovation Ambidexterity Mediates the Market

Orientation and New Product

Development Performance

Relationship.

Front. Psychol. 12:611293

doi: 10.3389/fpsyg.2021.611293

\section{Re-examining the New Product Paradox: How Innovation Ambidexterity Mediates the Market Orientation and New Product Development Performance Relationship}

\author{
Anni Zhao, Xinhua Bi* and Lei Han \\ Department of Management Science and Engineering, School of Management, Jilin University, Changchun, China
}

More and more well-documented failure of established companies which could not respond to rapid market changes, such as Kodak and Nokia, demonstrate the importance of transferring marketing information into real firm performance. While marketing strategy and management literature has long advocated the direct impact of strong firm market orientation (MO) on new product development (NPD) performance, limited research has discussed the mediating mechanism of this MO-NPD performance relationship. Using the traditional source-position-performance (SPP) framework, this study focuses on the innovation ambidexterity perspective to investigate the mediating mechanism between MO and NPD performance. Then, this study proposed a conceptual framework and propositions to examine the MO - NPD performance relationship further. Theoretical and practical implications of the findings are also discussed.

Keywords: market orientation, new product development performance, innovation ambidexterity, framework, marketing strategy

\section{INTRODUCTION}

William Bernbach, the co-founder of Doyle Dane Bernbach (one of the world's largest advertising holding companies), said, "An idea can turn to dust or magic, depending on the talent that rubs against it." The same is true of the innovation field. Even if these ideas did become real products, they were unable to remain long enough to achieve stable innovation performance. One example of these innovative, yet sadly unsuccessful products would be the Nokia. In contrast with Apple, Nokia missed the smartphone revolution because the company failed to predict what customers wanted. Long after the iPhone's release, Nokia continued to insist that its superior hardware designs and valuable brands would win over users. Even in 2010, Nokia still relied too much on its R\&D and research lab, introducing many disappointing phones. Its operating system made matters worse by proving too buggy, clunky, and unintuitive to win consumers over. When companies fall behind, consumers are quick to punish them (Srivastava and Ben-Aaron, 2011). To adapt and survive in today's increasingly dynamic business environment, previous marketing strategy and management literature also suggested that simultaneous exploration and 
exploitation-experimenting with innovation while improving existing technological capabilities-is prized (e.g., March, 1991; Kortmann, 2015; Zhang et al., 2016). "Innovation is increasingly exploratory the more it departs from knowledge used in prior innovation efforts and, conversely, increasingly exploitative the more deeply anchored it is in existing firm knowledge" (Benner and Tushman, 2003, p. 679). Thus, the case of Nokia and previous literature raised an exciting and imperative research question to answer: Engaging in exploring and exploiting activities, how can firms avoid the new product paradox to build reasonable and sensitive paths to improve innovation performance?

To fill these gaps in the literature, we focus the mechanism between market orientation (MO) on new product development (NPD) performance relationship from the traditional sourceposition-performance (SPP) framework (Day and Wensley, 1988). We propose that the SPP frameworks help the company gain a competitive advantage by re-examining the black-box from the relationship between MO and NPD performance. After reviewing the previous literature, we involve the strategic perspective to investigate the mechanism of the MO (Responsive and Proactive MO) - NPD performance relationship.

Research on "organizational ambidexterity" has well recognized the benefits to firm performance when keeping a closer balance between exploration and exploitation within organizations (e.g., Gibson and Birkinshaw, 2004; He and Wong, 2004; Gupta et al., 2006; Cao et al., 2009; Uotila et al., 2009; Heavey and Simsek, 2017; Koryak et al., 2018). Explorative capability refers to a firm's ability to identify and assimilate new scientific and technological knowledge. In contrast, exploitative capability refers to a firm's ability to transform and apply their existing knowledge and resources (March, 1991; He and Wong, 2004; Atuahene-Gima, 2005; Yalcinkaya et al., 2007; Lisboa et al., 2011). By involving explorative innovation, firms may take advantage of their existing resources to identify new technological opportunities and develop new products (Zhang et al., 2016). By pursuing exploitative innovation, firms may explore knowledge variants and develop new capabilities to "replace inefficient capabilities with more efficient ones" (Sirmon et al., 2011, p. 1402) to seek out future technology and market opportunities (Zhang et al., 2016). Following the traditional source-position-performance (SPP) framework, firms' strategic orientations (e.g., market orientation) play a crucial source role in driving innovation and "represent the ability of a business to do more or do better (or both) than its competitors" (Day and Wensley, 1988, p. 2), especially by the ambidextrous pursuit of both/or exploitative and explorative innovation (Zhang et al., 2016; Ghantous and Alnawas, 2020). Such source advantage may not automatically convert into sustainable performance. By adopting exploitative and/or explorative innovation, innovation ambidexterity works as the strategic perspective, creating a unique position advantage to transfer their knowledge and resources into performance. And Such a strategic perspective means the management and organizational capability to both compete in a mature market and to expand new products and services in an emerging market (Tushman and O'Reilly, 1996). This study contributes to the marketing/management literature and practices in several ways.
First, we extend Day and Wensley's (1988) SPP framework by further checking and exploring the mechanism between market orientation and NPD performance. Specifically, by adopting this classical SPP framework into the innovation context, we initially examined the important mediated role played by innovation ambidexterity between MO and NPD performance. Moreover, we extend the prior knowledge on the traditional market orientation and generate a conceptual framework to explore the relationship between responsive and proactive MO and NPD performance, mediated by innovation ambidexterity. Besides, we also proposed that the differential effects of responsive and proactive $\mathrm{MO}$ on NPD performance, which paves the way for future empirical studies on this research field. Finally, a good strategy can lead to detailed and tactical execution. Therefore, this research may guide managers about where to allocate their precious resources and efforts to improve their competitive advantage and NPD performance.

\section{LITERATURE REVIEW OF MARKET ORIENTATION (MO) AND NEW PRODUCT DEVELOPMENT (NPD) PERFORMANCE}

\section{Market Orientation (MO)}

Market orientation is a set of capabilities that establishes the customer's current and future needs first and then is focused on generating, disseminating, and using the information about customers and competitors to create superior value for the customers (Kohli and Jaworski, 1990; Narver and Slater, 1990). Deshpandé et al. (1993) only focused on the "customer orientation as the set of beliefs that puts the customer's interest first, while not excluding those of all other stakeholders such as owners, managers, and employees, to develop a longterm profitable enterprise" (p. 27). They found that selfreference and customer assessments of customer orientations are uncorrelated. Hence, the customer perspective serves as a reality check (Deshpandé et al., 1993). To avoid firms that may overemphasize their existing customers' needs and limit their innovative activities, Narver et al. (2004) suggested a more comprehensive and holistic approach to customer needs and solutions perspective, redefining another two types of MO: a responsive market orientation and a proactive market orientation. In this study, following Narver and his colleagues' new classification, we defined the responsive market orientation as the discovery of the customer's needs and solutions of which the customer is aware, while the proactive market orientation is the exploration of needs and solutions of which the customer is unaware.

As we can see from the above MO definition, it is essential to note that $\mathrm{MO}$ is conceptually and operationally different from organizational proficiency in performing marketing-related activities or market orientation in specific events, such as new product development field. In the following section, we will summarize the previous research findings related to the relationship between MO and NPD performance. 


\section{Literature Review for the MO-NPD Performance Relationship}

The previous literature has generalled that the new product success can be divided into different important antecedents, such as the competitive environment, the internal environment, or the new product development process (Song and Parry, 1997). In the following section, we focus on most of these factors to involve market orientation as the critical antecedent variables for NPD performance and summarize the previous research findings related to $\mathrm{MO}$ and NPD performance.

Atuahene-Gima (1995) presented the research question by observing how MO influences new product performance, and empirically tested that MO has a significant positive effect on new product performance and new product development activities. Song and Parry (1997) also found that firms in touch with the market may have a better understanding of customer wants and needs, competitor activities, and market trends, which can lead to better new product success. Wren et al. (2000) evaluated the impact that MO has on new product success in a cross-national context and found that MO is essential to new product success. By extending the measurement of both responsive market orientation and proactive market orientation, Narver et al. (2004) found that a responsive $\mathrm{MO}$ is not sufficient and, thus, that a proactive MO plays a vital positive role in a business's newproduct success. The relevant literature on responsive market orientation and proactive market orientation in the fields of management and marketing field are summarized in Table $\mathbf{1 .}$

So far, there are two major meta-analyses related to $\mathrm{MO}$ and NPD performance in marketing literature. Kirca et al. (2005) provided a summary of the bivariate findings regarding the antecedents and the consequences of MO. For the relationship between market orientation and innovation consequences, they found that market orientation has positive associations with both an organization's innovativeness $(r=0.45, p<0.05)$ and new product performance $(r=0.36, p<0.05)$. Grinstein (2008) found that overall market orientation is positively related to innovation consequences ( $r=0.396,95 \%$ of CI: $0.352-0.440)$. In addition, they also found that the three dimensions of $\mathrm{MO}$ has a positive effect to innovation consequences separately, customer orientation-innovation consequences $(r=0.411,95 \%$ of $\mathrm{CI}$ : 0.339-0.483), competitor orientation-innovation consequences ( $r=0.373,95 \%$ of $\mathrm{CI}: 0.268-0.478)$, and inter-functional coordination-innovation consequences $(r=0.392,95 \%$ of CI: 0.295-0.488).

Although most of the previous literature supports the positive relationship between $\mathrm{MO}$ and NPD performance (Wei and Morgan, 2004), there are some different opinions regarding the positive MO-NPD performance relationship. For example, some scholars argue that strict adherence to the tenets of the marketing concept philosophy leads to more miserable innovation activities and performance in the long run (Hayes and Abernathy, 1980). Also, empirical research provides inconclusive evidence on the influence of MO on new product development activities. For example, Baker and Sinkula (2009) found that MO does not influence firm innovation performance (profitability) directly, but entrepreneurial orientation (EO) does, so they concluded that market orientation and entrepreneurial orientation have a complementary effect on profitability in small businesses. What's more, in our in-depth interviews with some senior managers, we had the same dilemma that it is very difficult to earn superior innovation performance from their kinds of "innovative product." The environment is changing so quickly that the new product that costs lots of resources to develop is easily out of date, even before launching the product in the market. Therefore, in the following section, we try to re-investigate the mechanism between MO and NPD performance to figure out the black-box between the MO-NPD performance relationship.

\section{Re-examining the MO-NPD Performance Relationship}

The SPP model helps the firm develop a competitive advantage by using its resources and competencies. The basic ideas of the SPP model come out the sequential determinism of competitive advantage: the source $\rightarrow$ position $\rightarrow$ performance, which states that the source of firm or industry determines the position of firms (including their room for product differentiation or lowest delivered cost position), ultimately, in turn, determines their performance (including customer satisfaction, loyalty, market share, and profitability) (Day and Wensley, 1988). This framework provides a useful perspective for examining the relationship between $\mathrm{MO}$ and NPD performance. Adapting the above SPP model, Im and Workman (2004) found that new products (NP) and related marketing programs (MP, such as packaging, warranties, pricing, promotion, distribution) creativity mediates the relationship between market orientation and new product success. Langerak et al. (2004) tried to investigate the relationship among $\mathrm{MO} \rightarrow$ new product advantage/the proficiency in new product launch activities $\rightarrow$ new product performance $\rightarrow$ organizational performance.

In addition to these studies listed above, more studies are needed to explore the mechanism between $\mathrm{MO}$ and NPD performance. To address the research question of reexamining the black box between MO and NPD performance, we also employ Day and Wensley's (1988) source-positionperformance (SPP) framework for our conceptual model. Following the previous literature adopted the SPP framework in the marketing, management, and innovation literature (Im and Workman, 2004; Zhao et al., 2015), we believe such SPP framework is appropriate for examining the relationship between MO, innovation ambidexterity, and firm's NPD performance. Specifically, we propose that MO (responsive and proactive $\mathrm{MO}$ ) is a necessary, but not sufficient prerequisite for high firm performance. For achieving superior performance, the innovative firms must successfully "represent the ability of a business to do more or do better (or both) than its competitors" (Day and Wensley, 1988, p. 2), and develop and foster the right mix of innovation capabilities (i.e., exploitative and explorative innovation) to utilize their existing or new innovative capabilities to transfer their knowledge and resources into performance. In the following section, based on the SPP framework, we introduce the related constructs and develop the propositions in our conceptual model. 
TABLE 1 | A chronological review of the literature on responsive market orientation and proactive market orientation.

\begin{tabular}{|c|c|c|c|c|c|c|}
\hline References & Context & $\begin{array}{l}\text { Independent } \\
\text { variables }\end{array}$ & $\begin{array}{l}\text { Mediated } \\
\text { variables }\end{array}$ & $\begin{array}{l}\text { Moderator } \\
\text { variables }\end{array}$ & $\begin{array}{l}\text { Dependent } \\
\text { variables }\end{array}$ & Key findings \\
\hline $\begin{array}{l}\text { Narver et al. } \\
(2004)\end{array}$ & $\begin{array}{l}41 \text { technologically } \\
\text { business units } \\
\text { from } 25 \\
\text { companies }\end{array}$ & $\begin{array}{l}\text { Responsive } \mathrm{MO} \text {; } \\
\text { Proactive } \mathrm{MO} ; \\
\text { Innovation } \\
\text { Orientation }\end{array}$ & & & $\begin{array}{l}\text { New product } \\
\text { success }\end{array}$ & $\begin{array}{l}\text { An RMO is not sufficient and, thus, that a } \\
\mathrm{PMO} \text { plays a very important positive role in } \\
\text { a business's new-product success. }\end{array}$ \\
\hline $\begin{array}{l}\text { Atuahene- } \\
\text { Gima et al. } \\
\text { (2005) }\end{array}$ & 175 U.S. firms & $\begin{array}{l}\text { Responsive MO; } \\
\text { Proactive } \mathrm{MO}\end{array}$ & & $\begin{array}{l}\text { Strategic } \\
\text { consensus; } \\
\text { Learning } \\
\text { orientation; } \\
\text { Marketing's power } \\
\text { in the firm }\end{array}$ & $\begin{array}{l}\text { New product } \\
\text { performance }\end{array}$ & $\begin{array}{l}\text { RMO has a U-shaped relationship with } \\
\text { NPD, PMO has an inverted U-shaped } \\
\text { relationship with NPD; Joint effect has } \\
\text { negatively related to NPD; strategic } \\
\text { consensus (+) moderated responsive } \\
\text { MO-NPD; learning orientation and } \\
\text { marketing's power (+) moderated } \\
\text { proactive MO-NPD. }\end{array}$ \\
\hline $\begin{array}{l}\text { Tsai et al. } \\
\text { (2008) }\end{array}$ & $\begin{array}{l}384 \text { public } \\
\text { high-tech firm in } \\
\text { Taiwan }\end{array}$ & $\begin{array}{l}\text { Responsive MO; } \\
\text { Proactive } \mathrm{MO}\end{array}$ & & $\begin{array}{l}\text { Competitive } \\
\text { intensity; } \\
\text { technological } \\
\text { turbulence }\end{array}$ & $\begin{array}{l}\text { New product } \\
\text { performance }\end{array}$ & $\begin{array}{l}\text { Both PMO and RMO positively related to } \\
\text { NPD; PMO has an inverted U-shaped } \\
\text { relationship with NPD; TT (-) moderated } \\
\text { curvilinear RMO-NPD; Cl (+) moderated } \\
\text { curvilinear PMO-NPD. }\end{array}$ \\
\hline $\begin{array}{l}\text { Voola and } \\
\text { O'Cass (2010) }\end{array}$ & 189 Australia firm & $\begin{array}{l}\text { Differentiation; } \\
\text { cost leadership }\end{array}$ & $\begin{array}{l}\text { Responsive MO; } \\
\text { Proactive } \mathrm{MO}\end{array}$ & & Firm performance & $\begin{array}{l}\text { Both competitive strategies influence RMO } \\
\text { and PMO and firm performance. However, } \\
\text { the results show that differentiation } \\
\text { strategy has a stronger influence on RMO } \\
\text { and PMO than cost-leadership strategy, } \\
\text { and that PMO has a stronger influence on } \\
\text { performance than RMO. }\end{array}$ \\
\hline Bodlaj (2010) & $\begin{array}{l}325 \text { Slovenian } \\
\text { companies }\end{array}$ & $\begin{array}{l}\text { Responsive MO; } \\
\text { Proactive } \mathrm{MO}\end{array}$ & Degree of novelty & & Firm performance & $\begin{array}{l}\text { Only a PMO is positively related to the } \\
\text { degree of novelty. }\end{array}$ \\
\hline $\begin{array}{l}\text { Herhausen } \\
\text { (2016) }\end{array}$ & $\begin{array}{l}167 \text { two waves } \\
\text { survey data }\end{array}$ & $\begin{array}{l}\text { Responsive } \mathrm{MO} \text {; } \\
\text { Proactive } \mathrm{MO}\end{array}$ & & & $\begin{array}{l}\text { Market } \\
\text { performance }\end{array}$ & $\begin{array}{l}\text { Only PMO positively related to NPD; the } \\
\text { balance between proactive and } \\
\text { responsive market orientation has an } \\
\text { incremental positive effect on performance } \\
\text { beyond their combined effect; that } \\
\text { performance will decline less sharply when } \\
\text { proactive is higher than responsive market } \\
\text { orientation; and that as the level of } \\
\text { balance increases, performance will first } \\
\text { decrease and then increase. }\end{array}$ \\
\hline $\begin{array}{l}\text { Jaeger et al. } \\
(2016)\end{array}$ & $\begin{array}{l}\text { Panel data of } 56 \\
\text { US companies } \\
\text { observed over } 9 \\
\text { years }\end{array}$ & $\begin{array}{l}\text { Responsive } \mathrm{MO} \text {; } \\
\text { Proactive } \mathrm{MO}\end{array}$ & & & Firm performance & $\begin{array}{l}\text { PMO has a U-shaped relationship with } \\
\text { preperformance, RMO has an inverted } \\
\text { U-shaped relationship with } \\
\text { preperformance; the results confirm the } \\
\text { proposed inverted- } U \text {-shaped carry-over } \\
\text { effects of RMO, PMO exerts no carry-over } \\
\text { effects. }\end{array}$ \\
\hline
\end{tabular}

\section{The Mediation Effect of Innovation Ambidexterity on the MO-NPD Performance Relationship}

March (1991) defined that exploration requires "search, variation, experimentation, play, flexibility, discovery, and innovation," and exploitation requires "refinements, choice, production, efficiency, selection, implementation, and execution" (p. 71). Prior research builds on these perspectives and focuses on innovation ambidexterity, which is defined as a firm's ability to concurrently develop explorative and exploitative capabilities for innovation (Tushman and O'Reilly, 1996; He and Wong, 2004; Fernhaber and Patel, 2012; Lin et al., 2013). By involving exploitative innovation, firms may take advantage of their existing resources to identify new technological opportunities and develop new products (Zhang et al., 2016). By pursuing explorative innovation, firms may explore knowledge variants and develop new capabilities to "replace inefficient capabilities with more efficient ones" (Sirmon et al., 2011, p. 1402) to seek out future technology and market opportunities (Zhang et al., 2016). According to the previous literature, "MO is related to a firm's overall value and business philosophy about the importance of serving customers' needs" (Fang and Zou, 2009, p. 744), while, innovation ambidexterity (i.e., exploitative and explorative innovation) emphasize marketing process adjustment capabilities or activities in response to market changes and help a company respond to environmental changes through marketing 
and technological adaptation. Such adaptations are facilitated by processes such as resource integration, organizational learning, and knowledge management, enabling firms to maintain a sustainable advantage and achieve superior performance over their competitors (Xu et al., 2018). Since there are two distinctive types of $\mathrm{MO}$-responsive and proactive market orientation (Narver et al., 2004), in the following section, we turn our attention to investigate the effect of how responsive and proactive $\mathrm{MO}$ can facilitate innovation ambidexterity, ultimately increase firm new product development performance.

Exploitative innovation. In this research, we define exploitative innovation as the firms' capability that entails a shift away from its existing technological knowledge base, such that it enables the firm to enter new product-market domains. As we discussed above, exploitative innovation is an innovation that leverages current skills and capabilities, which enables the firm to improve existing product-market positions (Lavie et al., 2010). Exploitative innovation builds on existing marketing and technological knowledge and reinforces existing skills and processes (Lewin et al., 1999; Benner and Tushman, 2003). Moreover, the prior study has suggested that firms must pursue a customer-oriented philosophy and strengthen their marketing and sales skills to succeed in pursuing exploitative innovation (Atuahene-Gima, 2005). To boost such exploitative innovation, we propose that both responsive and proactive market orientation are essential.

As for the responsive market orientation, similar to the traditional measures of market orientation to discover the needs and solutions of a customer of which the customer is aware and can express, it has been approved as an essential factor in successful new product development (Atuahene-Gima, 1995; Atuahene-Gima and Ko, 2001; Narver et al., 2004). Following this logic, these firms are identified and committed to the organization's responsive customer-oriented value, such as understanding and serving the needs of current customers; they may excel in searching for their existing resources and using market information to serve the customer better (Day, 1994). Besides that, by leveraging their customer knowledge, they can become aware of market opportunities and improve their existing processes and resources to better satisfy existing customer needs (Yalcinkaya et al., 2007). In sum, by hearing customer's voices and adapting current offerings, responsive market orientation can help the company to foster exploit innovation opportunities, which allows them to take advantage of their existing learning and experience to address the customer's expressed needs; ultimately improve the firm performance (Ghantous and Alnawas, 2020).

Proactive market orientation aims to explore the needs and solutions of which the customer is unaware (Narver et al., 2004). A firm with a high proactive market orientation could entail the research for new and diverse market information fit for the firms' existing scope of knowledge and experience. By leveraging their existing resources and diverse marketing information, proactive firms may find and satisfy consumers' latent needs and guide the firm to emphasize the experimentation into their organizational activities. Focusing on future customer needs can also provide information to those firms about new markets and technology advancements to improve companies' capabilities to integrate existing resources into product innovation. Thus, we make the proposition that both responsive market orientation and proactive market orientation directly benefit an exploitative innovation, ultimately help to improve the NPD performance:

P1a: Exploitative innovation mediates the relationship between responsive $M O$ and NPD performance.

P1b: Exploitative innovation mediates the relationship between proactive $M O$ and NPD performance.

Explorative innovation. In this research, explorative innovation refers to firms' ability to identify and assimilate new scientific and technological knowledge. According to the definition, explorative innovation attempts to adopt new processes, products, and services that are unique from those used in the past (Levinthal and March, 1993; Yalcinkaya et al., 2007). Moreover, such explorative innovation requires new technological and market knowledge that departs from the firm's existing knowledge-base to better match the environment (Eisenhardt and Martin, 2000; Balboni et al., 2019; Wang et al., 2019). We also posit that both responsive and proactive market orientation are critical to boosting explorative innovation.

"Rome was not built in a day." Such responsive marketoriented firms not only respond to existing customer needs but also may uncover latent needs and anticipates future needs (Narver and Slater, 1990; Day, 1994). Thus, such firms may be eager to build on new capabilities (exploration), as existing ones (exploitation) become inadequate. When developing new technologies, those firms also can identify with their current customers who are appropriate for evaluating the products developed with those brand new technologies to ensure their success (Yalcinkaya et al., 2007). Besides, a firm with high responsive market orientation may deeply understand their current knowledge and experience resources, which may better able to integrate their existing knowledge to solve customers' problems and reduce the risks of exploration (Atuahene-Gima et al., 2005).

Sometimes, innovation is not just limited to slightly changing the existing product, but also takes the form of big ideas, means, or objects perceived by a person as something radically new. Through this track, innovation refers to the products which have not existed in the market in this period. In this situation, proactive market-oriented firms may be more associated with radical innovation than a responsive market orientation, which focuses on the company's current knowledge and experience to explore new technologies. Previous literature also suggested that firms with proactive market orientation enable the firm to nurture creative ideas and improves the firm's problemsolving capacity, thus advancing the effectiveness of exploration (Atuahene-Gima et al., 2005). Thus, we make the proposition that both responsive market orientation and proactive market orientation may benefit from an explorative innovation:

P2a: Explorative innovation mediates the relationship between responsive $M O$ and NPD performance.

P2b: Explorative innovation mediates the relationship between proactive $M O$ and NPD performance. 


\section{The Relative Effect of Market Orientation (Responsive and Proactive MO) on the Innovation Ambidexterity}

The knowledge about the business's customers and competitors could lead to more effectively market targeting, product development, and positioning (Hunt and Morgan, 1995; Atuahene-Gima and Ko, 2001). Proactive market orientation involves organizational processes for learning about the latent needs of current or potential customers, which may help the company adapt quickly to market shifts (Herhausen, 2016). In addition, proactive market orientation seems to foster the company to adopt some risky and fruitful strategies to lead and educate customers' latent needs. Apple can be the perfect example to show the power of proactive market orientation on explorative innovations. No customer gave Steve Jobs and Apple the design for the iPhone or the iPad. Instead of that, they came about from intense listening combined with a creative leap within their engineers to tackle and train customers' perceived needs (Guo et al., 2018). Therefore, proactive market orientation is more important to develop new products (explorative innovations) than responsive market orientation. In support of this argument, Narver et al. (2004) find that although both proactive and responsive market orientations are positively related to innovation, proactive market orientation may have a stronger effect than responsive market orientations. Consist of these empirical findings, another empirical paper also found that a (responsive) market orientation is not necessarily limited to incremental innovation (Baker and Sinkula, 2009).

As for the responsive market orientation, there are lots of business cases to prove in their efforts to satisfy customers' current needs. For example, Walmart, as one of the most efficient logistics companies, by continuously improving its physical handling and distribution processes (exploitative innovation), can seek to create superior value for customers primarily interested in low prices to satisfy their current needs. Previous literature also suggested that a responsive market orientation is viewed as contributing mainly to customer-led innovations but very little to major innovations (Yalcinkaya et al., 2007). Therefore, we propose that the responsive MO could more consistent with an exploitative learning strategy and have a more substantial effect on exploitative innovation than proactive MO. Thus, we make the following proposition:

P3a: The effect of proactive $M O$ on explorative innovations is stronger than responsive $M O$

P3b: The effect of responsive $M O$ on exploitative innovation is stronger than proactive $M O$

\section{DISCUSSION}

Drawing upon Day and Wensley (1988) classical SPP framework, we initially explore and investigate the mediating mechanism between market orientation and new product development (NPD) performance. More specifically, we propose that market orientation is a necessary, but not sufficient prerequisite for high firm performance. To maintain competitive advantages and achieve superior performance, previous research has empirically examined performance outcomes in general (e.g., innovation, profitability) by matching between a particular culture and other marketing mix factors to utilize their existing or new innovative capabilities to transfer their knowledge and resources into performance (Zhang et al., 2016). Therefore, we gain insight into extending the traditional market orientation into the proactive and responsive market orientation perspective to explore whether and how they have the mediating effects of fostering innovation ambidexterity, ultimately improving their NPD performance.

The findings of our conceptual model proposed that exploitative innovation mediates the relationship between $\mathrm{MO}$ (responsive MO and proactive MO) and NPD performance, and the explorative innovation also mediates the relationship between $\mathrm{MO}$ (responsive MO and proactive MO) and NPD performance. In addition, we also proposed that exploitative innovation and explorative innovation may have differential effects on the relationship between responsive and proactive MO and NPD performance. More specifically, the effect of proactive MO on explorative innovations is stronger than responsive $\mathrm{MO}$, while the effect of responsive $\mathrm{MO}$ on exploitative innovation is stronger than proactive MO. Next, we discuss the findings' implications to theory and managerial practice and the limitations and opportunities for future potential research.

\section{THEORETICAL IMPLICATIONS}

This research contributes to the marketing/management literature in the following approaches. First, we extend Day and Wensley's (1988) SPP framework by further checking and exploring the mediating mechanism between $\mathrm{MO}$ and NPD performance. Besides that, by adopting this classical SPP framework into the innovation context, we initially examined the important mediated role played by innovation ambidexterity between MO and NPD performance.

Furthermore, we extend traditional market orientation literature into two different angles- response $\mathrm{MO}$ and proactive $\mathrm{MO}$ to generate a conceptual framework to explore the relationship between responsive/proactive MO and NPD performance, mediated by innovation ambidexterity. Moreover, we also proposed that the differential effects of responsive/proactive $\mathrm{MO}$ to gain insight into how to foster the innovation ambidexterity, ultimately improve NPD performance. Such a conceptual model and propositions may pave the way for future empirical studies on this research field.

\section{MANAGERIAL IMPLICATIONS}

Our findings provide important implications for marketing managers. First, it can give marketing managers a new strategic direction to achieve competitive advantages and superior performance, especially for achieving new product development performance. The marketing managers should focus on both the "responsive and proactive market orientation" approach, enabling the business to compete by anticipating market requirements 
ahead of competitors and creating long-lasting relationships with customers, channel members, and suppliers (Gulati, 1999).

Also, there is an essential mechanism for giving marketing managers knowledge to transform responsive and proactive market orientation to new product development performance. Managers can spot opportunities and threats before rivals to guide managers on where to allocate their precious resources and efforts to balance with exploratory and exploitative innovations (Dai et al., 2017).

\section{LIMITATIONS AND FUTURE RESEARCH}

Several caveats bound the implications of our results, which offer interesting future research opportunities. First, this research only focuses on the mediating mechanism between MO and NPD performance. Some important antecedent variables for MO may be inevitably excluded in this research. Another limitation of this study is that this is a conceptual piece of a framework to explore the mediating mechanism between MO and NPD performance, more theoretical evaluation and different perspectives (RBV or $\mathrm{KBV}$ ) may be considered to examine the dynamic nature of the relationships we have discussed.

\section{REFERENCES}

Atuahene-Gima, K. (1995). An exploratory analysis of the impact of market orientation on new product performance. J. Prod. Innov. Manag. 12, 275-293. doi: 10.1111/1540-5885.1240275

Atuahene-Gima, K. (2005). Resolving the capability-rigidity paradox in new product innovation. J. Mark. 69, 61-83. doi: 10.1509/jmkg.2005.69.4.61

Atuahene-Gima, K., and Ko, A. (2001). An empirical investigation of the effect of market orientation and entrepreneurship orientation alignment on product innovation. Organ. Sci. 12, 54-74. doi: 10.1287/orsc.12.1.54.10121

Atuahene-Gima, K., Slater, S. F., and Olson, E. M. (2005). The contingent value of responsive and proactive market orientations for new product program performance. J. Prod. Innov. Manag. 22, 464-482. doi: $10.1111 / j .1540-5885.2005 .00144 . x$

Baker, W. E., and Sinkula, J. M. (2009). The complementary effects of market orientation and entrepreneurial orientation on profitability in small businesses. J. Small Bus. Manag. 47, 443-464. doi: 10.1111/j.1540-627X.2009.00278.x

Balboni, B., Bortoluzzi, G., Pugliese, R., and Tracogna, A. (2019). Business model evolution, contextual ambidexterity and the growth performance of high-tech start-ups. J. Bus. Res. 99, 115-124. doi: 10.1016/j.jbusres.2019. 02.029

Benner, M. J., and Tushman, M. L. (2003). Exploitation, exploration, and process management: the productivity dilemma revisited. Acad. Manag. Rev. 28, 238-256. doi: 10.5465/amr.2003.9416096

Bodlaj, M. (2010). The impact of a responsive and proactive market orientation on innovation and business performance. Econ. Bus. Rev. 12, 241-261.

Cao, Q., Gedajlovic, E., and Zhang, H. (2009). Unpacking organizational ambidexterity: dimensions, contingencies, and synergistic effects. Organ. Sci. 20, 781-796. doi: 10.1287/orsc.1090.0426

Dai, Y., Du, K., Byun, G., and Zhu, X. (2017). Ambidexterity in new ventures: the impact of new product development alliances and transactive memory systems. J. Bus. Res. 75, 77-85. doi: 10.1016/j.jbusres.2017.02.009

Day, G. S. (1994). The capabilities of market-driven organizations. J. Mark. 58, 37-52. doi: 10.1177/002224299405800404

Day, G. S., and Wensley, R. (1988). Assessing advantage: a framework for diagnosing competitive superiority. $J$ Mark. 52, $1-20$. doi: $10.1177 / 002224298805200201$
Second, this study only considered the strategic (innovation ambidexterity) perspective to investigate the mediating mechanism between MO and NPD performance, and other mechanisms (e.g., marketing capability, internal social capital integration, etc.) could be used in future research. At the same time, a key area for theory development would be to study what may influence the coexistence (joint effect) or strength of the direct effects we have examined.

Finally, this study only took the bright side of MO. In the future, an attempt to find some boundary conditions, and the empirical test will be interested in the marketing or management discipline. For example, organizational factors (e.g., organizational connectivity), industry and environmental factors (e.g., perceived environmental uncertainty), or cultural settings (e.g., individualism and collectivism) can be brought to bear as potential moderators.

\section{AUTHOR CONTRIBUTIONS}

$\mathrm{AZ}, \mathrm{XB}$, and LH: conceptualization. AZ: writing-original draft preparation and writing - review and editing.

Deshpandé, R., Farley, J. U., and Webster, F. E. Jr. (1993). Corporate culture, customer orientation, and innovativeness in Japanese firms: a quadrad analysis. J. Mark. 57, 23-37. doi: 10.1177/002224299305700102

Eisenhardt, K. M., and Martin, J. A. (2000). Dynamic capabilities: what are they? Strateg. Manag. J. 21, 1105-1121. doi: 10.1002/1097-0266(200010/11)21:10/11<1105::AID-SMJ133>3.0.CO;2-E

Fang, E. E., and Zou, S. (2009). Antecedents and consequences of marketing dynamic capabilities in international joint ventures. J. Int. Bus. Stud. 40, 742-761. doi: 10.1057/jibs.2008.96

Fernhaber, S. A., and Patel, P. C. (2012). How do young firms manage product portfolio complexity? The role of absorptive capacity and ambidexterity. Strateg. Manag. J. 33, 1516-1539. doi: 10.1002/smj.1994

Ghantous, N., and Alnawas, I. (2020). The differential and synergistic effects of market orientation and entrepreneurial orientation on hotel ambidexterity. J. Retail. Consum. Serv. 55:102072. doi: 10.1016/j.jretconser.2020.102072

Gibson, C. B., and Birkinshaw, J. (2004). The antecedents, consequences, and mediating role of organizational ambidexterity. Acad. Manag. J. 47, 209-226. doi: $10.2307 / 20159573$

Grinstein, A. (2008). The effect of market orientation and its components on innovation consequences: a meta-analysis. J. Acad. Mark. Sci. 36, 166-173. doi: 10.1007/s11747-007-0053-1

Gulati, R. (1999). Network location and learning: the influence of network resources and firm capabilities on alliance formation. Strateg. Manag. J. 20 397-420. doi: 10.1002/(SICI) 1097-0266(199905)20:5<397::AID-SMJ35>3.0.CO;2-K

Guo, H., Xu, H., Tang, C., Liu-Thompkins, Y., Guo, Z., and Dong, B. (2018). Comparing the impact of different marketing capabilities: empirical evidence from B2B firms in China. J. Bus. Res. 93, 79-89. doi: 10.1016/j.jbusres.2018.04.010

Gupta, A. K., Smith, K. G., and Shalley, C. E. (2006). The interplay between exploration and exploitation. Acad. Manag. J. 49, 693-706. doi: $10.5465 / \mathrm{amj} .2006 .22083026$

Hayes, R. H., and Abernathy, W. J. (1980). Managing our way to economic decline. Harvard Bus. Rev. 58, 138-149.

He, Z. L., and Wong, P. K. (2004). Exploration vs. exploitation: an empirical test of the ambidexterity hypothesis. Organ. Sci. 15, 481-494. doi: $10.1287 /$ orsc. 1040.0078 
Heavey, C., and Simsek, Z. (2017). Distributed cognition in top management teams and organizational ambidexterity: the influence of transactive memory systems. J. Manag. 43, 919-945. doi: 10.1177/0149206314545652

Herhausen, D. (2016). Unfolding the ambidextrous effects of proactive and responsive market orientation. J. Bus. Res. 69, 2585-2593. doi: 10.1016/j.jbusres.2015.10.139

Hunt, S. D., and Morgan, R. M. (1995). The comparative advantage theory of competition. J. Mark. 59, 1-15. doi: 10.1177/002224299505900201

Im, S., and Workman, Jr, J. P. (2004). Market orientation, creativity, and new product performance in high-technology firms. J. Mark. 68, 114-132. doi: 10.1509/jmkg.68.2.114.27788

Jaeger, N. A., Zacharias, N. A., and Brettel, M. (2016). Nonlinear and dynamic effects of responsive and proactive market orientation: a longitudinal investigation. Int. J. Res. Mark. 33, 767-779. doi: 10.1016/j.ijresmar.2016.01.006

Kirca, A. H., Jayachandran, S., and Bearden, W. O. (2005). Market orientation: a meta-analytic review and assessment of its antecedents and impact on performance. J. Mark. 69, 24-41. doi: 10.1509/jmkg.69.2.24.60761

Kohli, A. K., and Jaworski, B. J. (1990). Market orientation: the construct, research propositions, and managerial implications. J. Mark. 54, 1-18. doi: 10.1177/002224299005400201

Kortmann, S. (2015). The mediating role of strategic orientations on the relationship between ambidexterity-oriented decisions and innovative ambidexterity. J. Prod. Innov. Manag. 32, 666-684. doi: 10.1111/jpim.12151

Koryak, O., Lockett, A., Hayton, J., Nicolaou, N., and Mole, K. (2018). Disentangling the antecedents of ambidexterity: exploration and exploitation. Res. Policy 47, 413-427. doi: 10.1016/j.respol.2017.12.003

Langerak, F., Hultink, E. J., and Robben, H. S. (2004). The impact of market orientation, product advantage, and launch proficiency on new product performance and organizational performance. J. Prod. Innov. Manag. 21, 79-94. doi: 10.1111/j.0737-6782.2004.00059.x

Lavie, D., Stettner, U., and Tushman, M. L. (2010). Exploration and exploitation within and across organizations. Acad. Manag. Ann. 4, 109-155. doi: $10.5465 / 19416521003691287$

Levinthal, D. A., and March, J. G. (1993). The myopia of learning. Strateg. Manag. J. 14, 95-112. doi: 10.1002/smj.4250141009

Lewin, A. Y., Long, C. P., and Carroll, T. N. (1999). The coevolution of new organizational forms. Organ. Sci. 10, 535-550. doi: 10.1287/orsc.10.5.535

Lin, H. E., McDonough, E. F. III, Lin, S. J., and Lin, C. Y. Y. (2013). Managing the exploitation/exploration paradox: the role of a learning capability and innovation ambidexterity. J. Prod. Innov. Manag. 30, 262-278. doi: 10.1111/j.1540-5885.2012.00998.x

Lisboa, A., Skarmeas, D., and Lages, C. (2011). Entrepreneurial orientation, exploitative and explorative capabilities, and performance outcomes in export markets: a resource-based approach. Ind. Market. Manag. 40, 1274-1284. doi: 10.1016/j.indmarman.2011.10.013

March, J. G. (1991). Exploration and exploitation in organizational learning. Organ. Sci. 2, 71-87. doi: 10.1287/orsc.2.1.71

Narver, J. C., and Slater, S. F. (1990). The effect of a market orientation on business profitability. J. Mark. 54, 20-35. doi: 10.1177/002224299005400403

Narver, J. C., Slater, S. F., and MacLachlan, D. L. (2004). Responsive and proactive market orientation and new-product success. J. Prod. Innov. Manag. 21, 334-347. doi: 10.1111/j.0737-6782.2004.00086.x

Sirmon, D. G., Hitt, M. A., Ireland, R. D., and Gilbert, B. A. (2011). Resource orchestration to create competitive advantage: Breadth, depth, and life cycle effects. J. Manag. 37, 1390-1412. doi: 10.1177/0149206310385695
Song, X. M., and Parry, M. E. (1997). A cross-national comparative study of new product development processes: Japan and the United States. J. Mark. 61, 1-18. doi: 10.1177/002224299706100201

Srivastava, M., and Ben-Aaron, D. (2011). Nokia rethinks RandD spending. Availble online at: http://www.bloomberg.com/bw/stories/2011-02-14/nokiarethinks-r-and-dspendingbusinessweek-business-news-stock-market-andfinancial-advice (accessed 1 March 2019).

Tsai, K. H., Chou, C., and Kuo, J. H. (2008). The curvilinear relationships between responsive and proactive market orientations and new product performance: a contingent link. Ind. Mark. Manag., 37, 884-894. doi: 10.1016/j.indmarman.2007.03.005

Tushman, M. L., O'Reilly, C. A. III. (1996). Ambidextrous organizations: managing evolutionary and revolutionary change. Calif. Manag. Rev. 38, 8-29. doi: $10.2307 / 41165852$

Uotila, J., Maula, M., Keil, T., and Zahra, S. A. (2009). Exploration, exploitation, and financial performance: analysis of SandP 500 corporations. Strateg. Manag. J. 30, 221-231. doi: 10.1002/smj.738

Voola, R., and O'Cass, A. (2010). Implementing competitive strategies: the role of responsive and proactive market orientations. Eur. J. Mark., 44, 245-266. doi: 10.1108/03090561011008691

Wang, S. L., Luo, Y., Maksimov, V., Sun, J., and Celly, N. (2019). Achieving temporal ambidexterity in new ventures. J. Manag. Stud. 56, 788-822. doi: 10.1111 /joms. 12431

Wei, Y., and Morgan, N. A. (2004). Supportiveness of organizational climate, market orientation, and new product performance in Chinese firms. J. Prod. Innov. Manag. 21, 375-388. doi: 10.1111/j.0737-6782.2004.00092.x

Wren, B. M., Souder, W. E., and Berkowitz, D. (2000). Market orientation and new product development in global industrial firms. Ind. Mark. Manag., 29, 601-611. doi: 10.1016/S0019-8501(00)00120-6

Xu, H., Guo, H., Zhang, J., and Dang, A. (2018). Facilitating dynamic marketing capabilities development for domestic and foreign firms in an emerging economy. J. Bus. Res. 86, 141-152. doi: 10.1016/j.jbusres.2018.01.038

Yalcinkaya, G., Calantone, R. J., and Griffith, D. A. (2007). An examination of exploration and exploitation capabilities: Implications for product innovation and market performance. J. Int. Mark. 15, 63-93. doi: 10.1509/jimk. 15.4 .63

Zhang, J. A., Edgar, F., Geare, A., O'Kane, C. (2016). The interactive effects of entrepreneurial orientation and capability-based HRM on firm performance: the mediating role of innovation ambidexterity. Ind. Mark. Manag. 59, 131-143. doi: 10.1016/j.indmarman.2016.02.018

Zhao, Y. L., Libaers, D., and Song, M. (2015). First product success: a mediated moderating model of resources, founding team startup experience, and product-positioning strategy. J. Prod. Innov. Manag. 32, 441-458. doi: $10.1111 /$ jpim.12236

Conflict of Interest: The authors declare that the research was conducted in the absence of any commercial or financial relationships that could be construed as a potential conflict of interest.

Copyright (C) 2021 Zhao, Bi and Han. This is an open-access article distributed under the terms of the Creative Commons Attribution License (CC BY). The use, distribution or reproduction in other forums is permitted, provided the original author(s) and the copyright owner(s) are credited and that the original publication in this journal is cited, in accordance with accepted academic practice. No use, distribution or reproduction is permitted which does not comply with these terms. 